\title{
UMA CIÊNCIA DA MENTE: ELEMENTOS MENTAIS COMO PARTE DE UMA ARQUITETURA CIENTÍFICA
}

\author{
Sofia Inês Albornoz. Stein \\ UNISINOS
}

\begin{abstract}
RESUMO: Neste artigo, quero explorar a possibilidade de ver as experiências fenomênicas privadas, na linha do que pensava Russell, como detentoras de objetividade, o que possibilitaria vêlas como objetos de investigações científicas. Ou, dito de outro modo, perguntar se seria possível falar cientificamente sobre eventos mentais que chamamos ordinariamente de impressões. Apesar desse problema ser ainda considerado imperscrutável por uma certa filosofia, minha hipótese é a de que, como sustentava Sellars, podemos estar sendo apenas impedidos por erros ou limitações no uso de nosso vocabulário a encontrar uma solução consoante com ao que ambicionava Russell.
\end{abstract}

\begin{abstract}
In this article, I want to explore the possibility of seeing private fenomenal experiences along the line with Russell's thought: as having objectivity, which would allow seeing them as objects of scientific research. Or, in other words, to ask if it would be possible to speak scientifically about mental events usually called impressions. Although some philosophers still consider this problem to be inscrutable - the so-called explanatory gap that leads to all the complex and extense debate about qualia, my hypothesis is, as Sellars indicated, that it is highly probable that only errors or limitations in our use of vocabular impede us in finding a solution according to Russell's intention.
\end{abstract}

\section{A Questão}

Neste artigo, quero explorar a possibilidade de ver as experiências fenomênicas privadas, na linha do que pensava Russell, como detentoras de objetividade, o que possibilitaria vê-las como objetos de investigações científicas. Ou, dito de outro modo, perguntar se seria possível falar cientificamente sobre eventos mentais que chamamos ordinariamente de impressões. Apesar desse problema ser ainda considerado imperscrutável por uma certa filosofia, minha hipótese é a de que, como sustentava Sellars, podemos estar sendo apenas impedidos por erros ou limitações no uso de 
nosso vocabulário a encontrar uma solução consoante com ao que ambicionava Russell.

Segundo McDowell (1996 [1994], 1998, 2009, 2011), impressões sensoriais são incidências do mundo sobre um possuidor de capacidades racionais. Porém, para ele, que segue os passos de Sellars, o conteúdo empírico não deve ser visto apenas como um tipo de "responsividade a impressões". Sustenta, além disso, que, para explicar as diferenças entre nosso conhecimento empírico e as impressões "primitivas", não é necessário criar uma dicotomia entre o normativo de nossas capacidades racionais, que organizam material empírico, e o natural. O natural, por sua vez, não deveria ser visto como sendo equivalente às causas materiais, externas ou corporais, que resultam em impressões.

Como podemos manter o empirismo, pergunta McDowell, diante da constatação das diferentes naturezas de nossas capacidades racionais e de nossas capacidades perceptivas? As segundas parecem inseparáveis de um contexto regido por leis físicas que explicam redes causais em um mundo que chamamos de material. E não temos qualquer evidência para uma relação causal entre impressões sensoriais e atividades racionais. Temos, obviamente, e nisso concorda com Davidson (2001), conhecimento científico acerca da simultaneidade entre atividades racionais e eventos físico-químicos, porém isso não basta como evidência de relações causais entre ambos.

Outro ponto nevrálgico da argumentação de McDowell é a sua tentativa de manter a crença empirista em um tribunal da experiência, porém, em espécie, não-contraditório ao modo conceitual de conhecer humano, já naturalmente propenso a "ser conceitual". $\mathrm{Na}$ experiência humana, portanto, não encontraríamos nada de contraditório ao modo de expressão conceitual e proposicional do conhecimento humano, porém, ao contrário, a experiência já estaria, desde sua origem, nas impressões, harmonizada com a forma 


\section{Dossiê Naturalismo, Dissertatio - Volume Suplementar 02 | UFPel [2015]}

proposicional de expressão de conteúdos experienciados. Assim, a afirmação de McDowell de que não há dicotomia real entre o normativo e o natural parece salutar e, expressa apenas nesta forma muito simples, é também ecumênica, no sentido de poder ser aceita por naturalistas das mais diversas estirpes.

O naturalismo contemporâneo, percebe-se também nas linhas neohegelianas de $\mathrm{McD}$ owell, traz consigo a virtude de procurar pacificar a relação das ciências do homem com as da natureza. Porém, o discurso dicotômico com o qual expressamos o trajeto que vai de impressões a proposições não favorece a explicação do processo natural que se desenvolve de um a outro.

Ademais, resgatada em seu viés racionalista, a filosofia moderna contitui-se como força inicialmente antagônica ao naturalismo contemporâneo. Pois, na tradição naturalista mais radical, a relação homem x mundo natural é pressuposta e não é mais exigida prova transcendental dela. Portanto, a pergunta de McDowell sobre como respondemos ao mundo empírico que se mostra a nós por meio das impressões não é, em sentido estrito, a mesma pergunta de Kant, por pressupor a nossa inserção no mundo natural e não tentar prová-la. Claro, McDowell apela a Hegel em sua recusa da dicotomia fenómenos x coisas em si mesmas, mas isso é uma forma educada de dizer que a nossa natureza empírica é pressuposta.

O empirismo mínimo proposto por McDowell e a apresentação que dele faz em Mind and World (1996 [1994]), seguem, como mencionei, os passos de Sellars, que havia procurado, em 1956, em Empiricism and the Philosophy of Mind, refutar uma das principais teses do empirismo clássico, o Mito do Dado, porém mostrando como continuar admitindo a verdade do discurso ordinário sobre impressões e pensamentos.

Partindo dessa paisagem teórica, procurarei mostrar que o monismo neutro de Bertrand Russell já traz consigo argumentos naturalistas que 
conciliam a explicação causal, científica e fisicalista, de terceira pessoa, com a perspectiva fenomenalista de primeira pessoa. Portanto, minha trajetória argumentativa não focará exclusivamente na crítica sellarsiana ao Mito do Dado da tradição empirista, mas procurará mostrar que há nesta tradição um indício de conciliação entre o naturalismo e a perspectiva fenomenalista de primeira pessoa, que, talvez, complementadas pela crítica de Sellars, de inspiração wittgensteiniana, ao discurso de primeira pessoa sobre dados sensoriais, e às pretensões discursivas dogmáticas em geral, pode auxiliar, como já vislumbrado por mais de um filósofo, a pensar como investigar a mente humana.

Manter o discurso filosófico e científico sobre sensações ou dados sensoriais, por meio de sua naturalização, obviamente, como veremos, não responde completamente às críticas de Sellars, porque a ênfase na naturalização não dissolve a crítica ao problema semântico envolvido nas descrições empiristas de primeira e terceira pessoas, foco da crítica sellarsiana ao Mito do Dado. Mas procuramos aqui salvaguardar a importância do monismo neutro de Russell para a filosofia da mente contemporânea, reinterpretada por Sellars desde um viés da filosofia da linguagem. Minha análise pretende, então, dar razão a McDowell em sua pretensão de defender a tradição empirista, de um ponto de vista epistemológico, sem, no entanto, e agora não mais na linha de McDowell, abdicar de mostrar a possibilidade de utilizar esta mesma tradição para fundamentar uma espécie de metafísica das experiências de primeira pessoa, que, nas filosofias de Sellars e McDowell, ficam circunscritas por molduras transcendentais e semânticas. O resgate da metafísica empirista na filosofia da mente tem o potencial de aproximar essa última do cenário transdisciplinar atual das neurociências, que tem teor cientificista. Limitar o conhecimento da mente à nossa capacidade semântica de descrevê-la (cf. Sellars) ou de pensá-la (cf. McDowell) guarda, sem dúvida, 


\section{Dossiê Naturalismo, Dissertatio - Volume Suplementar 02 | UFPel [2015]}

uma parte da verdade sobre nossa cognição, pois aponta para uma característica essencial a qualquer linguagem, natural ou científica, qual seja, a de que qualquer ontologia depende da forma de conceituar. Não obstante isso, o realismo que assumimos na filosofia da mente deve, segundo entendo, não ser um realismo racionalista hegeliano, que estabelece um elo entre objetos e conceitos, ou entre fatos e pensamentos (como em Frege (1986) e McDowell). O realismo deve ser, em certo sentido, mais fraco que esse: deve pressupor a limitação racional e conceitual de conhecimento empírico. Simultaneamente, contudo, deve pressupor que seja possível, mediante avanços científicos, alcançar uma visão mais aprofundada da mente humana, e que não seja apenas uma tentativa ontologicamente relativa de descrição de fenômenos mentais, mas que ambicione avanços em direção a descrições mais fidedignas dos processos mentais humanos.

\section{O Monismo Neutro russelliano: objetivos e transformações conceituais}

Temos já muita literatura acumulada acerca da lacuna entre o ponto de vista ordinário da experiência perceptiva e o ponto de vista científico acerca de como opera o sistema perceptivo. Nenhuma discussão até hoje resultou na unificação dessas perspectivas, nem por meio de uma redução completa, nem por meio de uma teoria abrangente que pudesse mostrar as interações entre os objetos estabelecidos por ambos os pontos de vista. De um lado, os objetos da experiência subjetiva mediada pelo aprendizado linguístico intersubjetivo: impressões, sensações, percepções etc., e, de outro lado, os objetos de teorias anatômicas e fisiológicas: tecidos, nervos, impulsos elétricos etc.

Hoje, as neurociências parecem estar mostrando como impressões "subjetivas" são geradas a partir de uma rede causal que pode ser traçada 
cientificamente. Isso não prova que existam dados sensoriais, semelhantes aos descritos por Russell, porém corrobora o tipo de teoria causal da percepção que Russell estava elaborando entre 1910 e 1930.

O cientificismo que Russell elabora nos anos 1920 o leva, por exemplo, a negar a existência de entidades nominais tais como o "sujeito":

\begin{abstract}
The subject, however, appears to be a logical fiction, like mathematical points and instants. It is introduced, not because observation reveals it, but because it is linguistically convenient and apparently demanded by grammar. Nominal entities of this sort may or may not exist, but there is no good ground for assuming that they do. The functions that they appear to perform can always be performed by classes or series or other logical constructions, consisting of less dubious entities. If we are to avoid a perfectly gratuitous assumption, we must dispense with the subject as one of the actual ingredients of the world. But when we do this, the possibility of distinguishing the sensation from the sense-datum vanishes; at least I see no way of preserving the distinction. Accordingly the sensation that we have when we see a patch of colour simply is that patch of colour, an actual constituent of the physical world, and part of what physics is concerned with. (Russell, 1921, p. 142)
\end{abstract}

Para nossa investigação é importante perguntas por que Russell elimina, quando assume a perspectiva do monismo neutro, em 1921, o sujeito e mantém os sense-data, agora tornados equivalentes a sensações, que não são nem meramente mentais nem meramente físicas? Porque, podemos arriscar uma resposta, parece-lhe correto e necessário, tendo como princípio o atomismo epistemológico no qual se insere, que sensações sejam algo real e, em certo sentido, físico. Sem essa pressuposição, o elo causal entre objetos e percepção ficaria comprometido. Porém, para tanto, não lhe parece mais necessário sustentar que as sensações sejam determinadas em seu conteúdo e natureza por uma relação com um sujeito intencional e consciente. ${ }^{1}$ Como nos esclarece Hatfield:

${ }^{1}$ Não tratarei aqui das muitas questões que essa afirmação suscita, como, por exemplo, se existe uma unidade das representações mentais, se há um ponto de convergência das representações, o que seria 
As developed by James and Russell, neutral monism avoided the mind-body problem by positing only one "stuff", the allegedly neutral "stuff" of momentary particulars, or pure experiences, or Machian elements. Mach, James, and Russell could then point to two sets of laws to be found empirically in the successive states of this stuff: psychological laws governing successions of perceptions and other mental states considered as mental, and physical laws governing successions of perceptions and posited sensibilia, or unexperienced pure experiences, considered as physical. The mind-body relation then became a matter of tracing connections between physical sequences and intersecting psychological sequences of momentary particulars (as in Russell, 1921, ch. 15). (Hatfield, 2002, p.222)

Logo, apesar as mudanças nas leis explicativas do exclusivamente físico e do denominado psicológico, os particulares momentâneos, ou os elementos, em vocabulário de Mach, não precisariam ser chamados nem estritamente de físicos nem de psicológicos. Seriam "neutros", e poderiam ser explicados por leis tanto de teor fisicalista, quanto de teor psicológico.

Hoje, as neurociências não provam a existência de dados sensoriais, ou tampouco de sensações que seriam simultaneamente a experiência de dados sensoriais e os próprios dados sensoriais - dependendo da perspectiva com a qual essas fossem explicadas, porém mantêm o objetivo de Russell de encontrar a rede causal que vai desde os objetos físicos até a percepção "mental" deles. E essa rede tem de incluir formas variadas de "representações" das propriedades dos objetos. A observação da ativação neuronal durante o processo de percepção de objetos físicos levou à conclusão de que a percepção passa por várias etapas e que, em um sentido lato, os objetos são realmente construídos gradativamente em nosso cérebro, por meio das inter-relações que são estabelecidas entre diversas partes dele, cada uma exercendo uma função distinta.

uma consciência sem um sujeito ou um "eu", como a mente por ser intencional sem a pressuposição de um "eu" que seria o agente de intenções, etc. 
É óbvio que o acesso às próprias percepções ou sensações ainda é exclusivamente de primeira pessoa, o que mostra que a afirmação de Russell (1921) de que sensações são a interseção entre o mental (de primeira pessoa) e o físico (de terceira pessoa) ainda é bastante atual. Também é óbvio que a procura pela rede causal que leva dos objetos à percepção deles não dispensa a investigação acerca do que chamamos de "representação", um conceito ainda extremamente controverso tanto na filosofia quanto nas neurociências. E, por isso ser assim, métodos e testes têm de levar em conta o relato de primeira pessoa das experiências "subjetivas" representacionais.

Enfrentamos hoje um dilema disseminado na comunidade científica: on aceitamos as descrições ordinárias feitas por humanos das próprias experiências subjetivas (a sua "fala sobre impressões") e às correlacionamos ao que podemos observar cientificamente de alterações físicas que apresentam, como se fossem eventos paralelos, ou tentamos investigar de um ponto de vista behaviorista o que se passa fisicamente e em termos de comportamento com eles quando estão em certa posição de percepção, e desprezamos a descrição de primeira pessoa do mental, vinculando comportamento físico inicial a comportamento físico resultante. De qualquer forma, o elo entre experiências mentais ou psicológicas e comportamento físico inicial ou final ainda está por ser descoberto. Este elo Russell pensou ter encontrado nos dados sensoriais (sense-data), redefinidos, em 1921, como sensações.

Segundo Savage (1989), a mudança terminológica operada por Russell em 1921 poderia ser considerada realmente como uma espécie de redefinição do conceito de sense-data. O que foi considerado por alguns um abandono do próprio conceito de sense-data, é tratado por Savage como o abandono da atribuição de certas propriedades aos dados dos sentidos: 


\section{Dossiê Naturalismo, Dissertatio - Volume Suplementar 02 | UFPel [2015]}

(uninferred, self-evident), precise (analyzed, simple) data of empirical knowledge; and after abandonment were held to be only relatively certain, immediate, and precise, i.e. certain, immediate, and precise to some degree. (Savage, 1989, pp. 138139)

Assim como Savage, Tully (1988) crê que há uma continuidade no pensamento de Russell de 2014 até publicação de The Analysis of Matter (1927), passando por The Analysis of Mind (1921). E que, portanto, as mudanças terminológicas não consistiram em mudanças conceituais radicais, mas sim, em redefinições de conceitos já utilizados desde o princípio. Inicialmente, em 1914, Russell ainda é crítico aos novos realistas, como William James e Ernst Mach, por considerar suas posições um retrocesso, uma reaproximação a um idealismo das sensações, segundo o qual sensações se reduziriam a ideias, que passariam a ser o único elemento da realidade, idealismo que ele próprio tentou superar por meio da noção de familiaridade (acquaintance) entre o sujeito e dados objetivos oriundos dos sentidos. Entretanto, como frisa Tully (1988), ao contrário do que a crítica de Russell indica, os Novos Realistas pareciam conscientes do desafio de encontrar exatamente as entidades que poderiam ser consideradas tanto mentais ou psicológicas quanto objetivas ou físicas:

\footnotetext{
Interestingly, the New Realists appear to have been aware of the problem and, officially at least, designated neutral items as "qualities"; but he paid no attention to this when he accused their theory of being tainted with idealism. Whether a word like "quality" would in fact achieve what is wanted may be questioned, just as it may be wondered whether Russell's own use of the expression "sense-datum" could ensure the degree of objectivity and independence he required for the construction of physical objects. The problem of basic descriptions is a common one for empiricists, not just for those who defend neutral monism (Tully, 1988, p. 214).
}

Desta forma, não surpreende a seus intérpretes que, ao final da década de 1910, Russell tenha começado a achar atrativo a noção de "elemento 
neutro" talhada por Mach, um elemento nem meramente psicológico nem meramente físico, em sentido estrito ${ }^{2}$.

Russell passou a utilizar a expressão 'sensação' no lugar de 'dado dos sentidos' (sense-datum), a partir de 1921, porém essa mudança terminológica não significou propriamente um abandono de certas tendências filosóficas empiristas russellianas, que tinham como uma de suas linhas de pensamento a procura por uma base empírica para explicar os fenômenos mentais. Essa interpretação do desenvolvimento filosófico de Russell na filosofia da mente se justifica por ele ter mudado a terminologia em diversas ocasiões. Não foi, segundo Tully (1988), o monismo neutro que o levou a escolher a expressões “sensação" para substituir “sense-datum”, mas, aparentemente, foi uma espécie de procura pelo termo mais adequado para descrever algo que não era estritamente falando psicológico, e que deveria ser possível descrever desde uma ciência da mente humana. Logo após empregar a expressão "sensação" em substituição a "sense-datum", em 1921, Russell a substituiu por palavras como "percepto" e "qualidade". A decrescente ênfase no método introspectivo e na noção de familiaridade em escritos anteriores a The Analysis of Mind (1921), como em "The Relation of Sense-data to Physics" (1914b) e "On Propositions: What They Are and How They Mean" (1919) parece ter

\footnotetext{
${ }^{2}$ De acordo com Banks (2010), com base em sua análise das discussões das primeiras décadas do século XX, as três versões de monismo neutro, de William James, Ernst Mach e Bertrand Russell, podem ser, a grosso modo, sintetizadas por meio de quatro teses: "This historical climate of ideas ... left its stamp on the following theses about the nature of elements. I do not say that these theses are articulated by every classic neutral monist, but they are implicit in all three of them:

1. Monism: the mental and physical domains are part of a greater natural domain of elements and their functional variations.

2. Neutralism: elements are neither mental nor physical; rather minds and physical bodies are functionally related complexes of elements. Certain functional variations of the elements are called 'mental' and others are called 'physical', but there is no underlying duality of variations.

3. Psychophysical Identity: every sensation, such as green, is also a physical element (s/e), a neural energy in the brain. Not every element is a sensation, or even a possible sensation.

4. Powers: elements are powers with causal force. They are concrete qualities and dispositional ways of affecting things in their various causal, or functional, roles. The concrete quality instantiates the dispositional, relational role. Every element is naturally embedded in its functional role. (Banks, 2010, p.177)
} 


\title{
Dossiê Naturalismo, Dissertatio - Volume Suplementar 02 | UFPel [2015]
}

contribuído para Russell aproximar-se das visões dos novos realistas da mente, como as de James e Mach. Russell relata em "On Propositions" que o monismo neutro de James foi fazendo mais sentido conforme ele foi percebendo que era importante unificar os objetos físicos das investigações científicas, em especial, o cérebro, à uma investigação das atividades mentais. Segundo Tully:

\begin{abstract}
It is clear that Russell thought of neutral monism as a corrective to the other two varieties of monism which suffer from quite different but equally severe limitations, the one because it refuses to recognize the powerful role of inferential knowledge in science, the other because it fails to provide a systematic account of the ultimate dependency which such knowledge has on first-person experience. (Tully, 1988, p. 222)
\end{abstract}

Tully (1993) tenta explicar a guinada de Russell em 1914 em direção ao monismo neutro, após as críticas que formulou no mesmo ano (1914a) aos novos realistas —entre as quais se inclui a sua crítica à definição de crença formulada por eles e à falta de uma explicação satisfatória da experiência de primeira pessoa (subjetiva)—, mostrando a importância dada por Russell à unificação dos discursos da física e da psicologia, até 1914 considerados inconciliáveis:

In treating sensory particulars as the common subject matter of . both physics and psychology, Russell was adopting one of the tenets of the New Realism (or neutral monism, as the doctrine soon came to be called). In fact, the list of criticisms of neutral monism which he published in 1914 omitted this tenet; what he objected to rather was the neutral monists' account of belief and their tendency to dismiss the importance of first-person experience. Unobjectionable on other grounds, the hypothesis must have satisfied his desire for logical economy, but if Russell wanted to classify sense-data (or sensibilia) as physical, whatever qualitative familiarity they were allowed to have, how did he think these particulars become part of first-person experience? What kind of relation occurs when a sense-datum is experienced? Evidently, it takes more than a sense-datum plus the presence of a human body with functioning sense organs and a brain, for such things are themselves physical constructs whose ultimate constituents (in the eyes of physics) would 
mostly be sensibilia (or "ideal" appearances). The existence of a brain might be necessary for the experience of sense-data but is hardly sufficient. To this question Russell offered a forthright answer: "If — per impossibile - there were a complete human body with no mind inside it, all those sensibilia would exist, in relation to that body, which would be sense-data if there were a mind in the body. What the mind adds to sensibilia, in fact, is merely awareness: everything else is physical or physiological" ("The Relation of Sense-data to Physics", p. 8). (Tully, 1993, p. 12-13)

De 1914 até 1921, quando publica The Analysis of Mind, Russell, reelabora suas ideias acerca dos sense-data, adaptando-as às posições dos novos realistas. Porém, apesar das alterações conceituais e terminológicas, e da substituição de "sense-data" por "sensações" em 1921, como comenta Tully, essa substituição é menos substancial do que aparenta ser: Sensations have now been installed in place of sense-data, as required by the new thinking, though ironically their status (as particulars) was virtually identical to what had been previously accorded to sensedata. (Tully, 1993, p. 34)

Também Gary Hatfield (2002) nos alerta contra uma compreensão precipitada da posição de Russell em 1921, incitada por afirmações do próprio Russell em The Analysis of Mind, concordando, dessa forma, com Savage e Tully. Para justificar a substituição terminológica operada por Russell, vincula esta com a já mencionada recusa da manutenção de um sujeito para o qual se apresentariam os sense-data. O sujeito seria desnecessário no caso das "sensações", que seriam sequências de particulares momentâneos, e não precisariam ser particulares "para um sujeito":

When Russell became a neutral monist he also came to reject sense-data (1919/1956, p. 306; 1921, pp. 141-2; 1959, p. 135). Care must be taken in interpreting this change. In rejecting sense-data, he did not reject sequences of momentary particulars. Rather, he came to reject the distinction between such particulars and a subject who senses them. The particulars were no longer to be regarded as "data" for a subject, because the subject itself was denied. Or, to put it another way, the experience had by a certain subject is now 


\section{Dossiê Naturalismo, Dissertatio - Volume Suplementar 02 | UFPel [2015]}

regarded simply as a specific sequence from among the various sequences of momentary particulars that constitute everything, and which are the only particulars whose existence is explicitly allowed. (As we shall see, Russell did not flatly deny that the subject exists. but he took the theoretical attitude that its existence was not needed and should not be posited.) Russell's immediate particulars are now to be equated with the "elements" of James and Mach (as noted in Russell, 1919/1956, p. 305; 1914a/1956, p. 140). (Hatfield, 2002, p.208)

Quine (1966), embora condene, em Russell (1921), a manutenção de um discurso sobre "particulares neutros", que se assemelha, do seu ponto de vista, ao discurso sobre sense-data, de obras anteriores, elogia o fortalecimento do naturalismo ao Russell assumir o monismo neutro:

Russell meanwhile was warping his logical atomism over from its frankly phenomenalistic form to what, influenced by Perry and Holt, he called "neutral monism" (Cf. Analysis of Mind, p. 25; Analysis of Matter, ch. 37). Neutrality here has a bias, as it often has in politics; Russell's neutral particulars are on the side of sense data. Still, a drift has begun, and it continues. It does not reach the physicalistic pole, even in Human Knowledge; but there is an increasing naturalism, an increasing readiness to see philosophy as natural science trained upon itself and permitted free use of scientific findings. Russell had stated the basis for such an attitude already in 1914: "There is not any superfine brand of knowledge, obtainable by the philosopher, which can give us a standpoint from which to criticize the whole of the knowledge of daily life. The most that can be done is to examine and purify our common knowledge by an internal scrutiny, assuming the canons by which it has been obtained" (Our Knowledge of External World, p.71). (Quine, 1966, p. 667)

O monismo neutro, nas mãos de Russell, ganhou novos contornos empiristas e fisicalistas, que se beneficiaram de anos de experiência teórica de um dos mestres da lógica e da epistemologia do século XX. Sua obstinação em evitar o idealismo, por um lado, não foi suficiente para aproximá-lo de uma posição naturalista mais extremada, como ambicionada por Quine, porém, por outro lado, evitou sua adesão ao behaviorismo e ao eliminativismo, que 
dificultaram uma maior aproximação da filosofia quiniana às neurociências do final do último século.

\section{A Teoria da Percepção russelliana: a oscilação entre naturalismo e idealismo}

Em The Analysis of Mind (1921), Russell afirma que "we perceive things more or less, but always with a very considerable amount of vagueness and confusion" (p. 135). De sua teoria da percepção não é possível derivar uma posição realista forte acerca de objetos físicos percebidos. Russell oscila entre a posição empirista clássica e o fisicalismo. Para ele, se conseguirmos explicar a relação causal entre o objeto, o meio e o corpo humano, é possível estabelecer se a percepção é verídica ou não. Russell afirma:

\footnotetext{
When a mental occurrence can be regarded as an appearance of an object external to the brain, however irregular, or even as a confused appearance of several such objects, then we may regard it as having for its stimulus the object or objects in question, or their appearances at the sense-organ concerned. When ... a mental occurrence has not sufficient connection with objects external to the brain to be regarded as an appearance of such objects, then its physical causation (if any) will have to be sought in the brain. In the former case it can be called a perception; in the latter it cannot be so called. (Russell, 1921, p. 136)
}

A descrição russelliana de eventos de percepção mostra a oscilação entre empirismo e fisicalismo em sua filosofia da mente de 1921. E, além disso, poderíamos dizer, mostra que Russell já esposava uma espécie de naturalismo fisicalista, não-idealista ou solipsista, pois, apesar de falar em aparências e na obscuridade dos conteúdos de percepção enquanto aparências, não hesitava em afirmar a soberania da ciência física para estabelecer os vínculos causais entre objetos e experiências fenomênicas. 


\title{
Dossiê Naturalismo, Dissertatio - Volume Suplementar 02 | UFPel [2015]
}

Não há, em Russell, um mero paralelismo entre físico e mental. As aparências deveriam ser explicáveis por meio de leis físicas. No entanto, apesar do fisicalismo presente em sua teoria da percepção, mantém-se a lacuna entre o processo causal de percepção e a forma das aparências. E é por isso, como já vimos acima, que o monismo neutro de Russell coloca as sensações no núcleo da reflexão sobre os conteúdos do conhecimento empírico:

\begin{abstract}
Sensations are what is common to the mental and physical worlds; they may be defined as the intersection of mind and matter. This is by no means a new view; it is advocated, not only by the American authors I have mentioned (ex: William James], but by Mach in his Analysis of Sensations, which was published in 1886. ... It [sensation] is not itself knowledge, but it supplies the data for our knowledge of the physical world, including our own bodies. (Russell, 1921, p. 144)
\end{abstract}

Russell não inicia o discurso sobre os conteúdos da mente humana desde uma perspectiva meramente da primeira pessoa, e que gradativamente vai se desdobrando em uma explicação da correlação entre conteúdos da mente e aquilo a que designam ou deveriam designar, como ocorre na tentativa carnapiana (1928) de demonstrar a correlação entre mundo vivenciado humano e o conhecimento científico-conceitual. A tradição clássica, tanto racionalista quanto empirista, pressupõe a certeza acerca da perspectiva da primeira pessoa e "constrói" o mundo e/ou o conhecimento a partir desta. Isso sempre acontece com o auxílio dos conteúdos cognitivos que essa perspectiva coloca à disposição, isto é, ao explicarem como alcançamos conhecimento a partir de conteúdos fenomênicos, pressupõem que já se saiba quais são os conhecimentos resultantes deste processo. Assim, Carnap, por exemplo, mostra que é possível explicar como sentimos e percebemos já pressupondo conhecimentos que temos sobre o processo físico de sensação e percepção. Para Carnap, pois, a explicação filosófica não deveria partir apenas dos fatos descritos desde uma terceira pessoa, mas deveria mostrar como o processo se daria internamente ao sujeito que está sentindo e percebendo. Há, 
todavia, obviamente, uma circularidade no método expositivo que nenhuma afirmação anti-naturalista consegue evitar. Logo, a acusação que poderia ser feita aos neo-empiristas de caírem em uma posição idealista ou solipsista por iniciarem a descrição dos conteúdos da mente humana de um ponto de vista da primeira pessoa não se mantém se tivermos em vista que toda descrição de primeira pessoa recorre a conhecimentos que chamamos de terceira pessoa, conhecimentos sobre a relação entre o sujeito e o meio, que só a ciência fornece.

Isso significa que a análise do discurso de primeira pessoa depende da pressuposição de conhecimentos de terceira pessoa. O que, por sua vez, significa que a discussão sobre as sensações, que participam em percepções de objetos, é uma discussão de terceira pessoa que parece ser de primeira pessoa.

\section{Ciência da Mente e Discurso Ordinário: micro e macro-teorias}

Sellars (1956) mostrou isso até certo ponto. Contudo, apenas até o ponto de negar que o discurso sobre sensações seja útil para explicar o conhecimento empírico. Sellars identifica falácias na forma empirista de sustentar o Mito do Dado. Parcialmente porque o empirista afirma a existência de entidades particulares, dados sensoriais, que, no entanto, são, na verdade, o resultado de uma teoria acerca da percepção. Dados sensoriais não são detectáveis nem do ponto de vista da primeira, nem da terceira pessoa. São, portanto, estipulações (postulações) arbitrárias do filósofo empirista, que disserta acerca delas como se fossem, elas próprias, uma evidência. No Mito de Jones, elaborado por Sellars para explicar como pode ter-se originado o Mito do Dado, a teoria sobre impressões deriva da tentativa de explicar, na linguagem ordinária, experiências imediatas: 


\section{Dossiê Naturalismo, Dissertatio - Volume Suplementar 02 | UFPel [2015]}

Desse ponto de vista, é suficiente supor que o herói de meu mito postule uma classe de episódios internos - teóricos- que ele chama, digamos, impressões, e que são o resultado final dos impactos dos objetos físicos e processos sobre as várias partes do corpo, e, em particular, para levar adiante a forma específica na qual eu estabeleci nosso problema, os olhos. (Sellars, 2008 [1956], p. 112)

Embora a crítica de Sellars ao Mito do Dado faça sentido e não possa ser desconsiderada, eu não diria que seria uma ilusão categorial afirmarmos que dados sensoriais são o conteúdo primeiro do conhecimento empírico, se a ciência de terceira pessoa provasse que existem dados sensoriais. A esse respeito, é interessante analisar a seguinte passagem de Sellars:

Alguns filósofos pensaram ser óbvio que nós podemos esperar que no desenvolvimento da ciência se tornará razoável identificar todos os conceitos da teoria do comportamento com termos definíveis em teoria neurofisiológica, e esses, por sua vez, com termos definíveis em física teórica. É importante perceber que o segundo passo dessa predição no mínimo é ou um truísmo ou um engano. É um truísmo se envolver uma redefinição tácita de "teoria física" como significando "teoria adequada para explicar o comportamento observável de qualquer objeto (incluindo animais e pessoas) que têm propriedades físicas." Por outro lado, seria, creio, equivocado se "teoria física" for considerada em seu sentido ordinário de "teoria adequada para explicar o comportamento observável de objetos físicos."

Perguntar como impressões de adequam a campos eletromagnéticos, por exemplo, é perguntar uma questão equivocada. É misturar a estrutura da teoria comportamental molar com a estrutura da micro-teoria de objetos físicos. A questão apropriada seria, a saber, "O que corresponderia em uma micro-teoria de organismos sencientes a conceitos molares pertencentes a impressões?" E é, creio, respondendo a essa questão que nos defrontaríamos com os particulares que teóricos dos dados dos sentidos afirmam encontrar (por análise) no universo de discurso senso-comum (cf. seção 23). (Sellars, 2008 [1956], p. 115-116)

Considerando a citação acima, pode-se supor que Sellars não condenaria uma descrição de dados sensoriais que fosse parte de uma teoria 
científica sobre percepções humanas. Os dados sensoriais poderiam fazer parte do vocabulário técnico utilizado para descrever como organismos sencientes reagem internamente a impactos externos. $\mathrm{O}$ que não significaria que esses dados sensoriais seriam a referência particular de expressões como "vermelho" ou "triângulo". Impressões de vermelho ou de uma forma triangular podem fazer parte da micro-teoria que explica a reação de organismos sencientes ao meio, porém daí seria falacioso deduzir que a linguagem ordinária está errada ao atribuir aos objetos externos propriedades que são próprias às impressões resultantes de nossa relação senciente com esses objetos. Pelo contrário, o correto seria concluir que a micro-teoria pode explicar a relação entre os objetos físicos e as qualidades perceptivas que eles nos causam e que, segundo a micro-teoria, o senso comum está errado ao atribuir aos objetos qualidades que pertencem à percepção. Isso, entretanto, não deveria nos levar a "corrigir" a linguagem ordinária, pois estaríamos, neste caso, apenas substituindo uma teoria por outra; estaríamos substituindo o discurso fisicalista sobre qualidades de objetos externos por um discurso fenomenalista de terceira pessoa sobre qualidades percebidas que atribuímos a objetos externos que às causam.

Se interpretamos a filosofia da percepção russelliana de 1921 como uma espécie de cientificismo de teor fisicalista, que não reduz completamente sensações a eventos físicos, mas que permite pensar sensações como um aspecto (fenomênico) do mundo físico-material, então a crítica sellarsiana ao Mito do Dado não atinge seriamente a perspectiva de Russell, pois sua perspectiva não tem como método apenas a introspecção, mas, pelo contrário, aposta em evidências na ciência física para explicar a percepção. Todavia, Russell poderia ainda ser criticado por Sellars por priorizar a perspectiva fisicalista em detrimento à perspectiva do senso comum, por não perceber que ambas são, essencialmente, apenas duas linguagens e teorias diversas, que 


\section{Dossiê Naturalismo, Dissertatio - Volume Suplementar 02 UFPel [2015]}

atendem a objetivos pragmáticos diversos. Uma não seria mais verdadeira que a outra.

Se analisamos o que Sellars afirma acerca das diferenças entre linguagem ordinária e linguagem científica, podemos alcançar a conclusão de que o que ocorre em ambas é que ambas precisam falar de objetos distintos: a linguagem ordinária precisa falar de objetos físicos, esse é seu objetivo e é esta sua função; a linguagem cientifica que investiga a percepção envolvida no processo que resulta em atribuição de qualidades sensíveis a objetos físicos, está focada em descrever o processo de percepção e não o processo intersubjetivo de discurso sobre objetos físicos percebidos. A segunda quer explicar o processo de percepção, mesmo que este processo não seja transparente ao sujeito que percebe; a primeira serve ao sujeito senciente para comunicar aos seus interlocutores o que está ocorrendo no mundo físico, incluindo, talvez, em alguns casos, em seu corpo e em sua mente. Que, no primeiro caso, o sujeito atribua aos objetos qualidades que aparecem a ele de forma singular não significa que ele saiba qual o processo que levou à sua percepção singular dessas qualidades e à atribuição de palavras específicas a elas. $\mathrm{O}$ aprendizado de como relacionar palavras a experiências específicas não precisa passar pela teoria das impressões sensoriais que uma filosofia da percepção naturalizada procura elaborar com o auxílio das ciências. Uma das questões relevantes que permanece é sobre qual é a natureza da informação que o ponto de vista científico acrescenta ao ponto de vista ordinário.

\section{REFERÊNCIAS}

BANKS, Erik C. "Neutral monism reconsidered." Pbilosophical Psychology. v. 23, n. 2, April 2010, p. 173-187. 
BURGE, Tyler. "Disjunctivism and Perceptual Psychology." Philosophical Topics, v. 33, n. 1, Spring 2005, p. 1-78.

CARNAP, Rudolf. Der Logische Aufban der Welt. Hamburg: Felix Meiner Verlag, 1928.

CLARK, A. Being There. Putting Brain, Body, and World Together Again. London: Branford Books, 1998.

DAVIDSON, D. Essays on Actions and Events. $2^{\mathrm{a}}$ Ed. Oxford: Claredon Press, 2001.

FREGE, Gottlob. “Der Gedanke.” In Frege, G. Logische Untersuchungen (p. 3053). Göttingen: Vanderhoeck und Ruprecht, 1986.

HATFIELD, Gary. "Sense-data and the Philosophy of Mind: Russell, James and Mach." Principia, v. 6, n. 2, 2002, p. 203-30.

MACH, Ernst. Analyse der Empfindungen. Jena: Verlag von Gustav Fischer, 1922 [1886].

McDOWELL, John. "Naturalismo na Filosofia da Mente." Tradução Sofia I. A. Stein. Veritas, v. 58, n. 3, set./dez. 2013, p. 545-566. (Original: McDOWELL, John. "Naturalism in the Philosophy of Mind" [1999]. In: McDowell, John, The Engaged Intellect: Philosophical Essays. Cambridge, MA; London, UK: Harvard University Press, p. 257-275, 2009.)

McDOWELL, John. Perception as a Capacity for Knowledge. Millwaukee: Marquette University Press, 2011.

McDOWELL, John. The Engaged Intellect: Philosophical Essays. Cambridge, MA; London, UK: Harvard University Press, 2009.

McDOWELL, John. Meaning, Knowledge and Reality. London, UK; Cambridge, MA: Harvard University Press, 1998.

MCDOWELL, John. Mente e Mundo. Tradução João Vergílio G. Cuter. Ensaio Intr. Hilan Bensusan. Aparecida, SP: Idéias \& Letras, 2005 [1994]. 


\section{$\underline{\text { Dossiê Naturalismo, Dissertatio - Volume Suplementar 02 }}$ UFPel [2015]}

(Subjetividade Contemporânea). (Tradução de: McDOWELL, John. Mind and World. Cambridge; London: Harvard University Press, 1996 [1994].)

McDOWELL, John. "Intentionality and Interiority in Wittgenstein.” In: Puhl, Klaus (Ed.), Meaning Scepticism. Berlin; New York: Walter de Gruyter, p. 148169, 1991.

MILLIKAN, Ruth G. Language: A Biological Model. Oxford: Clarendon Press, 2005.

MILLIKAN, Ruth Garrett. V arieties of Meaning: The 2002 Jean Nicod Lectures. Cambridge: MIT Press, 2004.

MILLIKAN, Ruth G. On Clear and Confused Ideas: an Essay about Substance Concepts. Cambridge, UK: Cambridge University Press, 2000.

MILLIKAN, Ruth G. "Biosemantics." In: Millikan, R. G., White Queen Psychology and Other Essays for Alice. Cambridge; London: The MIT Press, p. 83102, 1993a.

MILLIKAN, Ruth G. "White Queen Psychology; or, The Last Myth of the Given.” In: Millikan, R. G., White Queen Psychology and Other Essays for Alice. Cambridge; London: The MIT Press, p. 279-363, 1993 b.

MILLLIKAN, Ruth Garrett. Language, Thought, and other Biological Categories: new foundations for realism. Cambridge; London: The MIT Press, 1984.

QUINE, W. V. "Russell's Ontological Development." The Journal of Philosophy, v. 63, n. 21, American Philosophical Association Eastern Division Sixty-Third Annual Meeting, Nov. 10, 1966, p. 657-667.

RUSSELL, B. "The Nature of Aquaintance" (1914a). In: . MARSH, Robert Charles (Ed.). Logic and Knowledge. London \& New York: Routledge, p. 125-174, 1956.

RUSSELL, B. "The Relation of Sense-data to Physics" (1914b). In: Mysticism and Logic. London: Longmans, Green, p. 145-79, 1918. 
RUSSELL, B. Our Knowledge of the External World. London: Allen S; Unwin, 1914c.

RUSSELL, B. "The Philosophy of Logical Atomism" (1918). In:

MARSH, Robert Charles (Ed.). Logic and Knowledge. London \& New York: Routledge, p. 125-174, 1956.

RUSSELL, B. "On Propositions: What They Are and How They Mean" (1919). In: - MARSH, Robert Charles (Ed.). Logic and Knowledge.

London \& New York: Routledge, p. 285-320, 1956.

RUSSELL, Bertrand. The Analysis of Mind. London: George Allen \& Unwin Ltd.; New York: The Macmillan Company, 1921.

RUSSELL, B. The Analysis of Matter. London: Kegan Paul, 1927.

SELLARS, W. Empirismo e Filosofia da Mente. Com uma introducão de Richard Rorty e um guia de estudos de Robert Brandom. Tradução de Sofia Inês Albornoz Stein. Petrópolis, RJ: Vozes, 2008. (Coleção Epistemologia) (Tradução de: Sellars, Wilfrid. Empiricism and the Philosophy of Mind. Cambridge, London: Harvard University Press, 1997 [1956].)

SAVAGE, C. Wade. "Sense-Data in Russell's Theories of Knowledge." Minnesota Studies in Philosophy of Science, v. 12, 1989, p. 138-168.

STEIN, Sofia I. A. Van Orman Quine: Epistemologia, Semântica e Ontologia. London: College Publications, 2009. (Filosofia Contemporânea e História da Filosofia).

TULLY, Robert. "Russell's neutral monism." Russell: The Journal of the Bertrand Russell Arcbives. v. 8, n. 1, 1988, p. 209-224.

TULLY, Robert. “Three Studies of Russell's Neutral Monism.” Russell: The Journal of the Bertrand Russell Archives, v. 13, n. 5, 1993, p. 5-35.

WITTGENSTEIN, Ludwig. Philosophical Investigations. Translated by G.E.M. Anscombe. 2. Ed. 1958. (Tradução de: WITTGENSTEIN, L. (1990 [1953]). 
Philosophische Untersuchungen. In: Werkausgabe. Band I. Frankfurt am Main: Suhrkamp, p.225-580, 1990.) WRIGHT, Crispin. "McDowell's Oscillation." Philosophy and Phenomenological Research, v. LVIII, n. 2, June 1998, p. 395-402.

WRIGHT, Crispin. "Wittgenstein's Later Philosophy of Mind: Sensation, Privacy, and Intention." The Journal of Philosophy, v. 86, n. 11, Nov. 1989, p. $622-$ 634. 